\title{
Influence of nutrient input on the trophic state of a tropical brackish water lagoon
}

\author{
D Ganguly ${ }^{1,3, *}$, Sivaji Patra ${ }^{1}$, Pradipta R Muduli $^{2}, \mathrm{~K}_{\text {Vishnu Vardhan }}{ }^{1}$, \\ Abhilash K R $\mathrm{R}^{1,3}$, R S Robin ${ }^{1,3}$ and B R Subramanian ${ }^{3}$ \\ ${ }^{1}$ ICMAM Project Directorate, Ministry of Earth Sciences, NIOT Campus, Chennai 600 100, India. \\ ${ }^{2}$ Wetland Research and Training Centre, Chilika Development Authority, Odisha 752 030, India. \\ ${ }^{3}$ National Centre for Sustainable Coastal Management, MOEF, Chennai 600 025, India. \\ *Corresponding author.e-mail: dipnarayan.ganguly@gmail.com
}

Ecosystem level changes in water quality and biotic communities in coastal lagoons have been associated with intensification of anthropogenic pressures. In light of incipient changes in Asia's largest brackish water lagoon (Chilika, India), an examination of different dissolved nutrients distribution and phytoplankton biomass, was conducted through seasonal water quality monitoring in the year 2011. The lagoon showed both spatial and temporal variation in nutrient concentration, mostly altered by freshwater input, regulated the chlorophyll distribution as well. Dissolved inorganic N:P ratio in the lagoon showed nitrogen limitation in May and December, 2011. Chlorophyll in the lagoon varied between 3.38 and $17.66 \mathrm{mg} \mathrm{m}^{-3}$. Spatially, northern part of the lagoon showed higher values of DIN and chlorophyll during most part of the year, except in May, when highest DIN was recorded in the southern part. Statistical analysis revealed that dissolved $\mathrm{NH}_{4}^{+}-\mathrm{N}$ and urea could combinedly explain $43 \%$ of Chlorophyll- $a$ (Chl-a) variability which was relatively higher than that explained by $\mathrm{NO}_{3}^{-}-\mathrm{N}$ and $\mathrm{NO}_{2}^{-}-\mathrm{N}(12.4 \%)$ in lagoon water. Trophic state index calculated for different sectors of the lagoon confirmed the intersectoral and inter-seasonal shift from mesotrophic to eutrophic conditions largely depending on nutrient rich freshwater input.

\section{Introduction}

During the last few decades, several research works have been carried out on the nutrient dynamics of estuaries, ocean and fresh waters. These nutrients are present in natural waters both in organic and inorganic forms. Inorganic nitrogen occurs in the form of nitrate, nitrite and ammonia which can be readily consumed by the phytoplankton with different degree of preference. Elevated concentration of dissolved inorganic nitrogen (DIN) results in increased phytoplankton production and biomass, which may in turn be followed by increased population of consumer animals. At the same time excessive nutrient enrichment can be detrimental to the aquatic water bodies. Changes in nutrient concentration can shift the competitive advantage between different phytoplankton species. Also, it can change the chlorophyll specific carbon uptake rate by the individual species (Ganguly et al. 2013). These modifications at the primary producer level can have significant impact on the net ecosystem metabolism as well as its biodiversity. Apart from DIN, dissolved organic nitrogen (DON) is also recognized to be a dynamic component of the nitrogen pool in aquatic systems (Seitzinger et al. 2002; Berman and Bronk 2003) and has also been suggested to accumulate seasonally in coastal waters (Miyazaki et al. 2010; Violaki et al. 2010). Among DON, urea alone accounts for $11-65 \%$ of

Keywords. Chilika lagoon; dissolved inorganic nitrogen; urea; chlorophyll; trophic state. 
water-soluble organic nitrogen (Mace et al. 2003). Indeed, urea has a range of natural and anthropogenic sources; it is the most widely applied nitrogen fertilizer in many parts of the world (Glibert et al. 2005). However, its use has increased exponentially such that urea presently accounts for $50 \%$ of current global nitrogen (N) fertilizer applications (Glibert et al. 2006). In the present day, urea appears to be a reliable tracer of the diffusion of wastewaters in the coastal marine environment, more specific and sensitive than other nutrients, with a behaviour that also reflects the technology of the treatment plants (Cozzi et al. 2014). In addition, a large number of studies have shown that urea is an important source of $\mathrm{N}$ for a great variety of marine phytoplankton, ranking often in importance as much as, or greater than, nitrate (Kudela and Cochlan 2000). Coastal waters can be supplied with urea through terrestrial and atmospheric inputs (Middelburg and Nieuwenhuize 2000; Glibert et al. 2001) and transfer from sediments (Rysgaard et al. 1998). Urea uptake by phytoplankton communities as a percentage of total nitrogen uptake can contribute upto $50 \%$ of the total nitrogen taken up in coastal and estuarine regions (e.g., Chesapeake Bay, Glibert et al. 1991; Gulf of Bothnia, Sweden, Cochlan and Wikner 1993, etc.). With concentrations that often exceed $1 \mu \mathrm{M}-\mathrm{N}$, urea can be a significant nitrogen source for phytoplankton. Besides this, knowledge on urea uptake can give precised estimation of $f$ ratio (ratio of new to total production) which is often used to examine the biological efficiency of that ecosystem (Allen et al. 2002). Despite its significant influence, records on dissolved urea distribution along the Indian coastal waters and its impact on the ecosystem have not been studied much. A coastal water body like Chilika which regularly receives a large amount of fresh water (through 19 rivers/rivulets) carrying significantly high amount of inorganic and organic load, could easily be affected by any change in agricultural practices in the catchment area. Since 1980-2009, the increase in total nitrogen fertilizer used in Orissa state was reported to be $\sim 600 \%$ (http://www.agriorissa.org/pdf/ FertilizerConsumptioninOrissa.pdf). This could significantly influence the aquatic bodies (at its ecosystem level) situated in and along the state. On the basis of its physicochemical properties, the trophic state of the lagoon like Chilika can be classified as one of the four general classes, i.e., (1) oligotrophic (meaning low nutrient level and high clarity), (2) mesotrohic (a moderate elevation in nutrient concentrations resulting in lower clarity and a reduced desirable biological habitat), (3) eutrophic, (the enriched state), and (4) hyper-eutrophic (the most enriched environment which can result in substantial loss of environmental qualities). In order to quantitatively assess the present trophic status of the lagoon ecosystem along with its important regulating parameters, trophic state index (TSI) could be very useful (Carlson 1977, 1991; Lee et al. 2010). These types of studies defining the trophic status are very few in Indian waters. The objective of the present study was to evaluate the significance of nutrient concentrations available at a varying degree at different seasons and sectors of the tropical lagoon, to support the phytoplankton primary production. Special emphasis was given to find the abundance and role of dissolved urea in phytoplankton biomass distribution in the lagoon water. Trophic state of the entire lagoon was also determined for the first time by using seasonally observed data.

\section{Study area}

Chilika $\left(19^{\circ} 28^{\prime}-19^{\circ} 54^{\prime} \mathrm{N} ; 85^{\circ} 06^{\prime}-85^{\circ} 35^{\prime} \mathrm{E}\right)$, the largest brackish water lagoon in Asia, has been designated as a Ramsar site on the Ramsar Convention of Wetlands in 1981. The shallow water body (average depth $2 \mathrm{~m}$ ) is about $65 \mathrm{~km}$ in length, spreading from northeast to southwest parallel to the coastline with a variable breadth reaching $20.1 \mathrm{~km}$. The lagoon is spread over an area of $950 \mathrm{~km}^{2}$ during summer, which swells up to $1165 \mathrm{~km}^{2}$ during monsoon (Siddiqui and Rao 1995). The lagoon is connected to the Bay of Bengal near Satapara (Sipakuda) by means of an artificial opening made in September 2000. High evaporation from the shallow water body during the summer and large inflow of fresh water through various rivers and rivulets at the northern end of the lagoon during the monsoon and post-monsoon seasons contribute significantly to the water spread area. The catchment area of the lagoon is $4406 \mathrm{~km}^{2}$, in which $68 \%$ is constituted by western catchment and $32 \%$ by the Mahanadi delta, with an average rainfall of $1238 \mathrm{~mm}$ (southwest or summer monsoon); nearly $75 \%$ of it occurs during the southwest monsoon. 19 rivers/rivulets (R1-R19; figure 19) drain enormous fresh water into the lagoon together with significant loads of nutrients and suspended matter resulting in appreciable changes in hydrological conditions both seasonally as well as annually. While the northeast rivers (e.g., Makara (R15), Daya (R16), Nuna (R17), Bhargavi (R18)) representing the Mahanadi system contributes $68-85 \%$ of total freshwater discharge, the western rivers (e.g., Janjira (R4), Kansari (R5), Kusumi (R7), Tarimi (R10), etc.) account for the rest (figure 1). During pre-monsoon, there is practically no discharge from northwest rivers (R8-R14). Flow from all the rivers reached a maximum during monsoon 


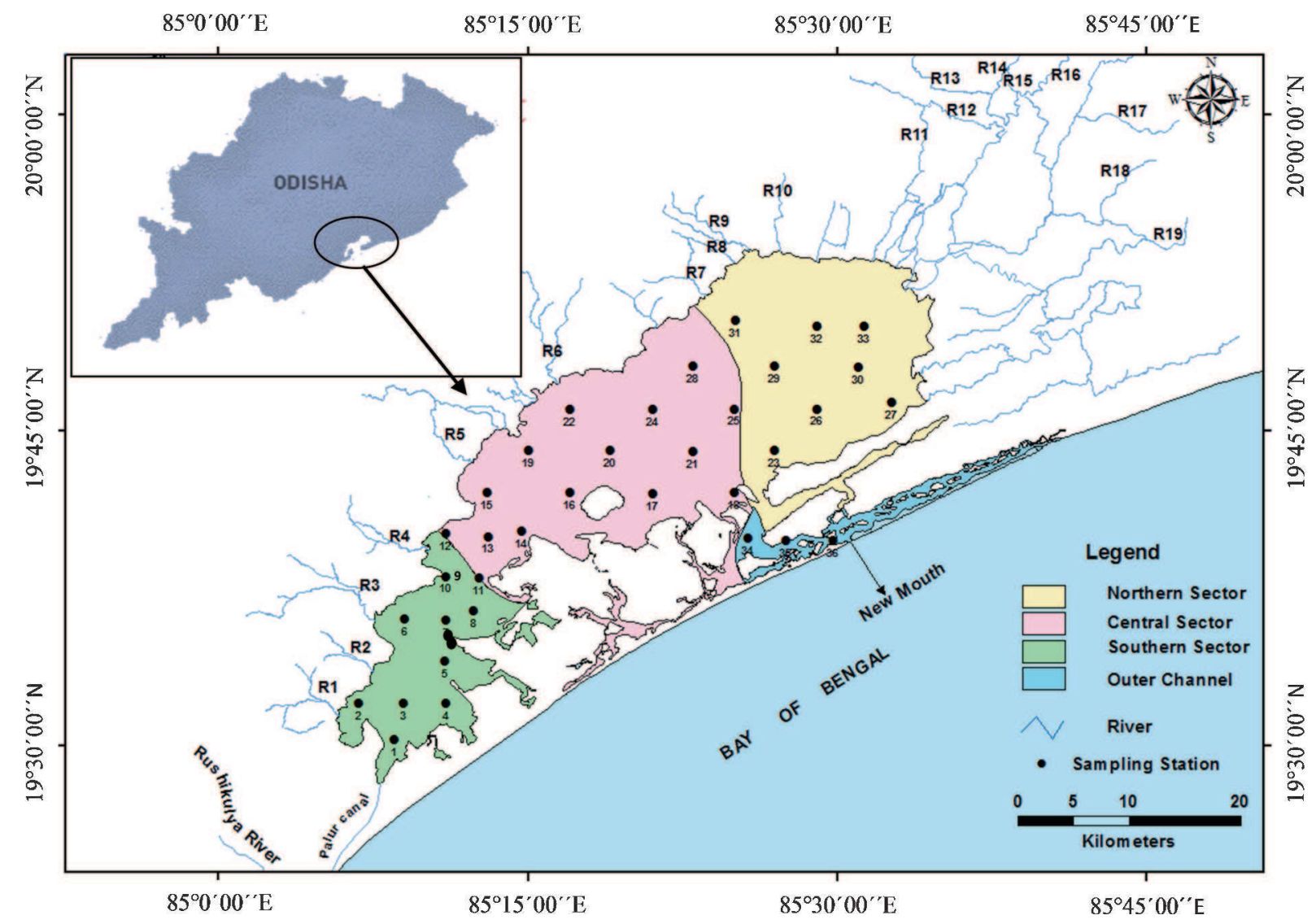

Figure 1. Location of the Chilika Lagoon and the sampling stations (R1-R19 are the 19 rivers draining into the lagoon).

followed by significant reduction in post- and premonsoon. Ecologically, the shallow lagoon represents a combined character of marine, brackish and freshwater ecosystems (Muduli et al. 2012) with very low water column stratification.

\section{Material and method}

\subsection{Sampling and analysis}

For sampling in pre-monsoon, monsoon and post-monsoon, three representative months (May, August and December, 2011) were selected. Three independent observations were carried out seasonally during the representative months corresponding to each season, viz., pre-monsoon (May), monsoon (August) and post-monsoon (December) for the year 2011, covering a spread of 36 hydrologically differing stations representing the south (1-14), central $(15-17,19-21,23)$, north $(22,24-33)$ sectors and the outer channel $(18,34-36)$ (figure 1). Sectorwise zonation of the selected stations was done by following the earlier research works carried out in the same stations (Gupta et al. 2008; Muduli et al. 2012). Seasonal group average clustering from Euclidean distances by using salinity, nutrient and chlorophyll concentrations derived from the present study also supported the previous grouping of all the stations into identical sectors (Muduli et al. 2013). The air temperature and wind velocity were also recorded using automatic probes (DAVIS $7440)$. Surface water samples $(\sim 0.2 \mathrm{~m})$ were collected during the daytime of each sampling month (each seasonal sampling lasted for five consecutive days) assuming steady state conditions during the sampling period as the tidal amplitude inside the lake is negligible (Gupta et al. 2008). Earlier studies revealed the well mixed nature of the water column and very low vertical stratification in the lagoon (Mahapatro et al. 2013). At the inlet front (lagoon mouth), the tide was little more prominent than the rest of the lagoon and it was mostly semidiurnal in nature with a maximum tidal range of $1.2 \mathrm{~m}$ in spring time. However, in the main body of the lagoon, the effect of tidal variation was found comparatively less with order of 5-20 cm.

Nutrient samples were collected in acid-cleaned buckets and Niskin-type bottles. The water was filtered through combusted GF/F filters (47 mm Whatman) and stored frozen in HDPE bottles (cleaned with a phosphate-free soap solution). Analysis was completed on the same day of collection (except urea). DIP (dissolved inorganic 
phosphate) and DIN (dissolved inorganic nitrogen as the addition of nitrate, nitrite and ammonium concentrations) (Grasshoff et al. 1999) were analyzed using spectrophotometer (Model-1650 Shimadzu). In order to estimate urea concentration, the direct chemical method introduced by Revilla et al. (2005) was followed. Each sample (4 ml) was treated with the colour developing reagent which consisted 1 part of reagent A (3.4 g of diacetylmonoxime in $100 \mathrm{ml}$ of doubled distilled water (DDW) $)$ and 3.2 parts of reagent $\mathrm{B}(300 \mathrm{ml}$ of concentrated sulfuric acid diluted to $535 \mathrm{ml}$ with DDW together with $0.5 \mathrm{ml}$ of a ferric chloride solution [0.15 g of ferric chloride in $10 \mathrm{ml}$ of DDW]). After $72 \mathrm{hr}$ of incubation at room temperature, urea concentration of each sample was calculated spectrophotometrically by measuring the absorbance at $520 \mathrm{~nm}$. Total dissolved phosphorus (TDP) and total dissolved nitrogen (TDN) in the seawater were determined by alkaline persulphate oxidation (filtered water) following digestion with a buffer mixture (potassium peroxo disulphate, boric acid and sodium hydroxide) and by the spectrophotometric method (Grasshoff et al. 1999). Dissolve organic nitrogen (DON) and dissolve organic phosphorous (DOP) were calculated as the difference between TDN/TDP and DIN/DIP, respectively. Suspended matter (SPM) was collected by filtering one litre of each sample through $0.45 \mu \mathrm{m}$ cellulose acetate membrane (Millipore) filters followed by drying the filters at about $75^{\circ} \mathrm{C}$ to constant weight. SPM was expressed as the difference between the final and the initial weight of the filter paper. Particulate organic nitrogen was measured by the method given by Labry et al. (2002) whereas particulate organic phosphorous was measured by the method given by Valderrama (1981); Pujo-Pay and Raimbault (1994). Total nitrogen (TN) was computed from the sum of TDN and particulate organic nitrogen (PON). Similarly, total phosphorus (TP) was calculated as the summation of TDP and POP. The transparency of the water was measured using a Secchi disk (SD) to define the euphotic layer. The water samples were filtered through $\mathrm{GF} / \mathrm{F}$ Whatman filter paper for the analysis of chlorophyll- $a(\mathrm{Chl}-a)$. Measurement of the acetone extract was done by means of a UV-visible spectrophotometer.

Net primary production (NPP) was measured at 11 selected stations (St. no. 3, 6, 13, 18, 19, 20, $23,26,29,33,35)$ by in situ ${ }^{14} \mathrm{C}$ assimilation method (UNESCO 1994). Surface waters (water samples filtered to remove grazers) in perfectly transparent Nalgene bottles (two light and one dark) were inoculated with labeled $\mathrm{NaH}^{14} \mathrm{CO}_{3}$ (activity $5 \mu \mathrm{Ci} \mathrm{ml}^{-1}$; BARC, Mumbai) and incubated at in situ conditions (at $\sim 0.4 \mathrm{~m}$ depth at high tide condition) for $12 \mathrm{hr}$ (06:00-18:00 hr) during the day. The light availability during day time at the incubation depth was always maintained above the light saturation level (calculated from the laboratory experiment for the major phytoplankton species available in Chilika waters; unpublished data) using an underwater spectral radiometer (Satlantic Model Hyper OCRII). The Nalgene bottles were tightly capped and attached to a rope hanging from a buoy and suspended at the same sampling depths. On retrieval, samples were immediately passed through Whatman GF/F filter paper under gentle suction. The filters, after exposing to concentrated hydrochloric acid fumes for a minute, were preserved in scintillation vials until analysis. Later, these filters were treated with $5 \mathrm{ml}$ scintillation cocktail in dioxane and the radioactivity was measured using a liquid scintillation counter (Wallac 1409 DSA, Perkin Elmer, USA). NPP rates were calculated based on a $12 \mathrm{hr}$ photo-period and expressed as $\mathrm{mg} \mathrm{C} \mathrm{m} \mathrm{m}^{-3} \mathrm{~d}^{-1}$.

\subsection{Statistical analysis}

One way ANOVA test was performed to determine spatio-temporal variation between various parameters (salinity, primary productivity, etc.) in the lagoon. Stepwise multiple regression analysis was carried out to determine the relative importance of various biologically active water quality parameters (independent variable) in regulating the water column Chl- $a$ concentration (dependent variable) in the lagoon.

Trophic state indices (TSI) of the reservoir were calculated using the four equations (Secchi disk, $\mathrm{TSI}_{\mathrm{SD}}$; total nitrogen, $\mathrm{TSI}_{\mathrm{TN}}$; chlorophyll pigments, $\mathrm{TSI}_{\mathrm{CHL}}$; and total phosphorus, $\mathrm{TSI}_{\mathrm{TP}}$ ) described by Carlson (1977) and Kratzer and Brezonik (1981). The equations are as follows:

$$
\begin{aligned}
& \mathrm{TSI}_{\mathrm{SD}}=60-14.42 \ln (\mathrm{SD}) \\
& \mathrm{TSI}_{\mathrm{TN}}=54.45+14.43 \ln (\mathrm{TN}) \\
& \mathrm{TSI}_{\mathrm{TP}}=14.42 \ln (\mathrm{TP})+4.15 \\
& \mathrm{TSI}_{\mathrm{CHL}}=9.81 \ln (\mathrm{Chl})+30.6
\end{aligned}
$$

where SD was in meters, TP and Chl- $a$ were in $\mathrm{mg}$ $\mathrm{m}^{-3}$ and TN was in $\mathrm{mg} \mathrm{l}^{-1}$. The waters with TSI $<40$ are grouped into oligotrophic state, and the waters with TSI ranging from 40 to 50 are distinguished into mesotrophic state. If the TSI values range from 50 to 70 , the waters belong to eutrophic state. The value of TSI higher than 70, suggests hypertrophic state (Kratzer and Brezonik 1981). All mathematical and statistical computations were made using Excel 2007 (Microsoft Office) and Minitab 16. 


\section{Results and discussion}

\subsection{Lagoon hydrography and nutrients}

The hydrography of the Chilika lagoon is largely driven by fresh water, supplied from the upstream watersheds as well as seawater exchange through the outer channel. Small tidal amplitude in the lagoon indicated its lesser influence over the hydrological characters, whereas, the wind induced churning of bottom sediment indicates the possible
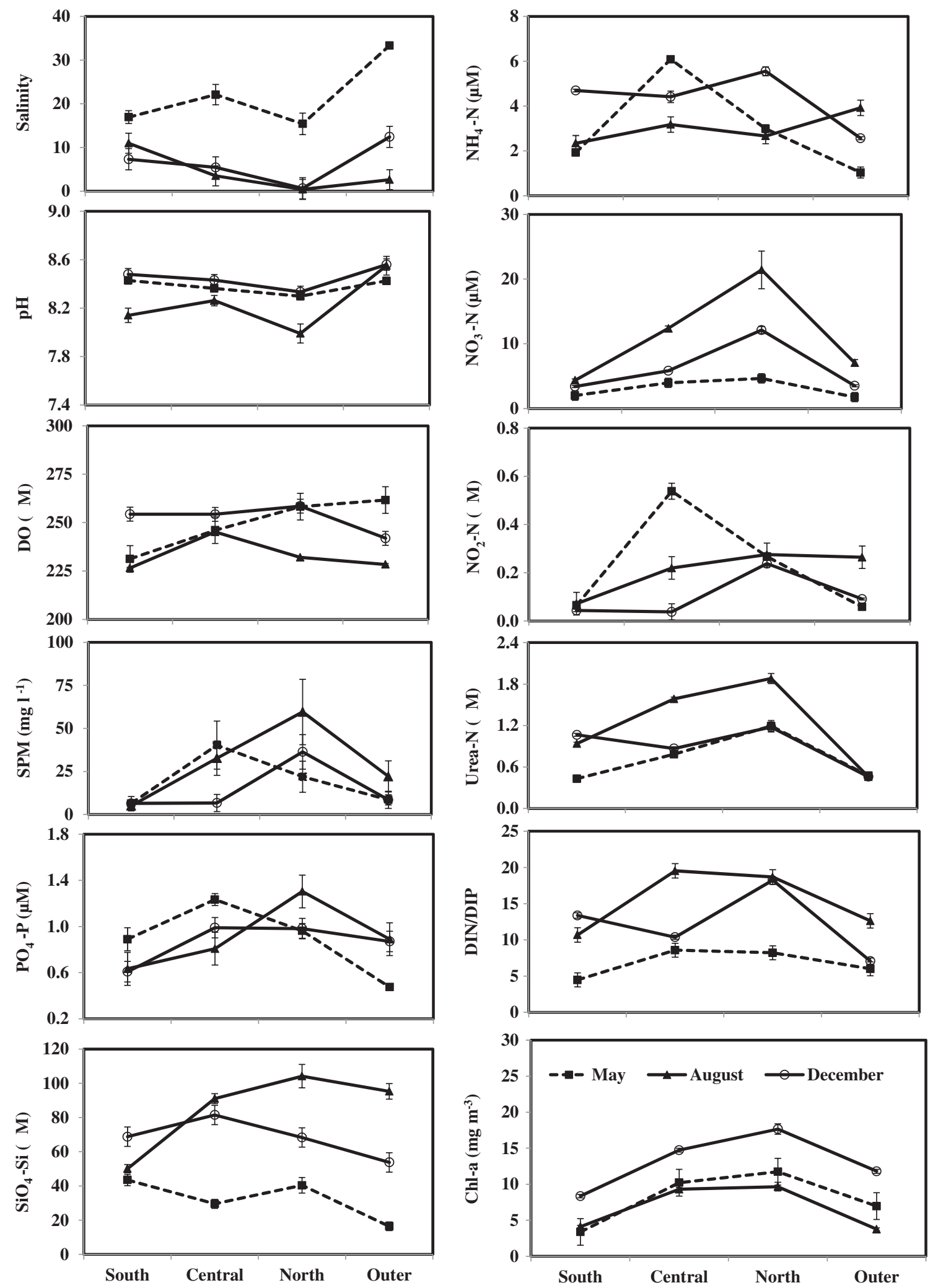

Figure 2. Sectoral mean of water quality parameters at the Chilika lagoon during May, August and December, 2011. 
influence of the suspended particles in the water lagoon remains significantly different from one anochemistry and other in situ metabolic activities. ther with respect to depth, transparency, salinity, The three sectors and the outer channel of the DO, nitrite-N, nitrate-N, ammonia-N, phosphate-P,

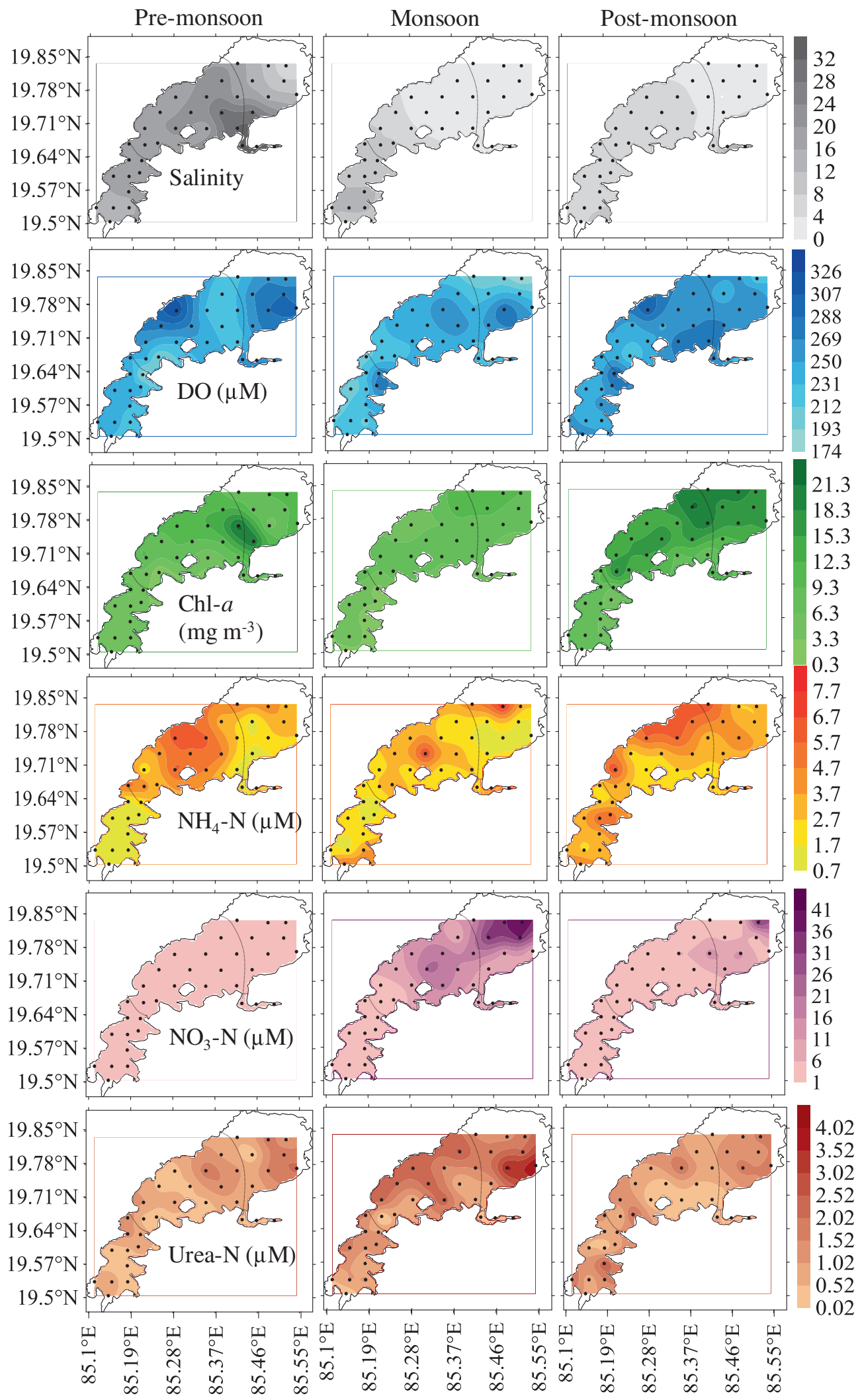

Figure 3. Spatio-temporal distribution of (a) ammonia-nitrogen, (b) nitrate-nitrogen, (c) urea-nitrogen, (d) salinity, (e) DO, (f) Chl- $a$ in the Chilika lagoon. 
TN, TP and chlorophyll- $a$ concentration. A welldefined spatio-temporal heterogeneity in the distribution of various water quality parameters was observed in the lagoon. Mean lagoon salinity reached the maximum value during pre-monsoon when the fresh water discharge was the minimum and sea water exchange through the outer channel was the most dominant. The highly dynamic character of the estuary is highlighted by the fact that all the sites experienced almost the entire range of salinities. Previous studies showed that the major sources of inorganic nutrients were through the river discharge as evident from their maximum concentrations during monsoon season. The results of the present study showed almost the similar spatio-temporal pattern of the lagoon hydrography and nutrient distribution as those reported in some of the previous studies (Nayak 2004; Gupta et al. 2008; Panigrahi et al. 2009; Muduli et al. 2012; Kanuri et al. 2013 and others). Seasonal variation of different water quality parameters (salinity, pH, DO, spm, nutrients and chlorophyll-a) during this present study, at four different sectors of the lagoon are given in figure 2. The spatio-temporal distributions of the water quality parameters, was presented in the surface plot (figure 3), which shows a clear pattern in the distribution of those water quality parameters in a spatial gradient over the whole lagoon, during the study. The salinity $(p<0.05$ and $p=0.006)$ and DIN concentration $(p=0.003, p<0.001)$ in the Chilika lagoon showed significant variation between the seasons and the sectors. The relative contribution of the inorganic $\mathrm{N}$ species in total DIN $\left(\mathrm{NO}_{3}^{-}-\mathrm{N}+\mathrm{NH}_{4}^{+}-\mathrm{N}+\mathrm{NO}_{2}^{-}-\mathrm{N}\right)$ during three sampling months at different sectors, are expressed in table 1 . The relative increase in $\mathrm{NH}_{4}^{+}-\mathrm{N}$ fraction from monsoon to post-monsoon months could be associated with several biogeochemical processes dominated by dissimilatory nitrate reduction to ammonium (DNRA; Dunn et al. 2012) and in situ mineralization of dissolved and particulate organic matter in this shallow tropical lagoon. Except in the monsoon months, the DIN:DIP ratio in the lagoon remained well below the Redfield ratio.

\subsection{Distribution of dissolved organic nitrogen and phosphorous}

Dissolved organic nitrogen (DON) in the lagoon showed significant spatio-temporal variation with mean seasonal values of $42.9 \pm 7.65,35.51 \pm 5.32$ and $39.93 \pm 5.01 \mu \mathrm{M}$ during May, August and December, respectively. In May 2011, exceptionally high DON concentration was observed in the northern sector $(64.31 \pm 12.23 \mu \mathrm{M})$, which coincided with relatively higher Chl- $a$ concentration compared to the other sectors. A substantial dilution of DON concentration in the northern sector was recorded during August with the introduction of riverine fresh water in to the lagoon. Among various forms of DON available in the lagoon, urea concentration ranged between 0.02 and $4.16 \mu \mathrm{M}$ which was higher than the values reported in Florida Bay (Glibert et al. 2004) but considerably less than different parts of Chesapeake Bay, Maryland (Glibert et al. 2005). Mean lagoon concentrations of urea-N in May, August and December, 2011 , were found to be $0.72 \pm 0.35,1.28 \pm 0.73$ and $0.89 \pm 0.31 \mu \mathrm{M}$, respectively. Highest and lowest

Table 1. Comparison of relative percentage contribution of urea- $N$ concentration with those of dissolved inorganic- $\mathrm{N}\left(\mathrm{DIN}=\mathrm{NH}_{4}^{+}+\mathrm{NO}_{3}^{-}+\mathrm{NO}_{2}^{-}\right)$during May, August and December, 2011.

\begin{tabular}{|c|c|c|c|c|c|c|}
\hline Season & Sector & $\mathrm{DIN}(\mu \mathrm{M})$ & $\% \mathrm{NH}_{4}$ & $\% \mathrm{NO}_{3}$ & $\% \mathrm{NO}_{2}$ & \%Urea \\
\hline \multirow[t]{5}{*}{ PRM } & South & $3.99 \pm 1.61$ & 48 & 50 & 2 & 10 \\
\hline & Central & $10.59 \pm 3.49$ & 57 & 37 & 5 & 7 \\
\hline & North & $7.91 \pm 1.73$ & 38 & 59 & 3 & 13 \\
\hline & Outer & $2.85 \pm 0.09$ & 36 & 62 & 2 & 14 \\
\hline & Mean & & 45 & 52 & 3 & 11 \\
\hline \multirow[t]{5}{*}{ MN } & South & $6.77 \pm 1.57$ & 35 & 64 & 1 & 12 \\
\hline & Central & $15.77 \pm 7.45$ & 20 & 78 & 1 & 9 \\
\hline & North & $24.37 \pm 13.98$ & 11 & 88 & 1 & 7 \\
\hline & Outer & $11.24 \pm 6.89$ & 35 & 63 & 2 & 4 \\
\hline & Mean & & 25 & 73 & 1 & 8 \\
\hline \multirow[t]{5}{*}{ PM } & South & $8.14 \pm 2.28$ & 58 & 42 & 1 & 12 \\
\hline & Central & $10.27 \pm 3.23$ & 43 & 57 & 0 & 8 \\
\hline & North & $17.92 \pm 9.50$ & 31 & 68 & 1 & 6 \\
\hline & Outer & $6.17 \pm 0.97$ & 42 & 57 & 1 & 7 \\
\hline & Mean & & 43 & 56 & 1 & 9 \\
\hline
\end{tabular}

$\%$ urea $=($ urea concentration $\times 100) /$ DIN concentration. 
urea- $\mathrm{N}$ concentration was recorded at the northern sector and the outer channel, respectively, during all the sampling months. The relative contribution of urea (being a member of DON family) was expressed as percentage of total DIN (urea\% = [Urea concentration $\times 100] /$ DIN concentration).

Although there were dilutions in DON from premonsoon to monsoon, higher mean urea-N concentration was recorded in the later season with the highest value recorded at station 27 in the northern sector during August (4.16 $\mu \mathrm{M})$. Urea showed a significant negative relation with the lagoon salinity $\left(r^{2}=0.47, p=0.01\right)$, which indicated its terrestrial origin and gradual dilution towards the higher salinity waters. Table 2 represents the range of concentrations of urea $(\mu \mathrm{M}-\mathrm{N})$ from some coastal and estuarine sites including the present study. The contribution of urea to the total DON ranged between 1.1 (December) and 8.37\% (August). The higher contribution of urea in DON in the northern sector was attributed to the monsoonal increase in its supply and a decrease in DON in the lagoon water. The relative contribution of urea- $\mathrm{N}$ with respect to inorganic- $\mathrm{N}$ concentrations in lagoon waters was maximum during May although highest urea concentrations were observed during monsoon. Sectorwise, urea-N showed its maximum contribution with respect to DIN concentration at the outer channel during pre-monsoon. Formation of intermediates like urea during DON mineralization at a higher salinity (Berman and Bronk 2003) could explain its relatively higher contribution during this part of the year. During May, when the riverine contribution was very small, percentage of inorganic nitrogen in the lagoon waters was the minimum and the major form of nitrogen was organic. In shallow coastal ecosystems like Chilika, remineralization of organic matter in the sediment/ suspended particle could often be a major source of dissolved inorganic as well as organic nutrients in the water column. The relative contributions of $\mathrm{NO}_{3}^{-}-\mathrm{N}$ and urea were higher in the outer channel than other parts of the lagoon, in pre-monsoon but the concentrations were not significantly varying $(p>0.05)$ from the adjacent northern sector. During the post-monsoon, the contributions of both these components (inorganic + organic) were almost comparable in the lagoon waters even though there existed a predominance of the organic form for the rest of the year. Scatterplot between DON and Chl- $a$, during May when freshwater flow to the lagoon was very low, revealed a strong positive association, where $58 \%$ of variability of Chl- $a$ concentration was explained by DON $\left(r^{2}=0.58, \mathrm{n}=34, \mathrm{p}=0.003\right)$ (figure 4). No such significant relation was observed $(p>0.05)$ in the other two sampling months. These results indicated the preference of the primary producers present in the lagoon to utilize the regenerated DON (in May) as a nutrient over the anthropogenically derived DON (August and December). Similar observations were made from the Chesapeake Bay by Bronk and Glibert (1993), where a higher degree of regenerated DON uptake by the phytoplankton was recorded in summer than in spring. Mean lagoon DOP was maximum in August $(1.95 \mu \mathrm{M})$ followed by May $(1.71 \mu \mathrm{M})$ and December $(0.79 \mu \mathrm{M})$. Among the sectors, northern and central sectors showed higher DOP values compared to rest of the lagoon throughout the year.

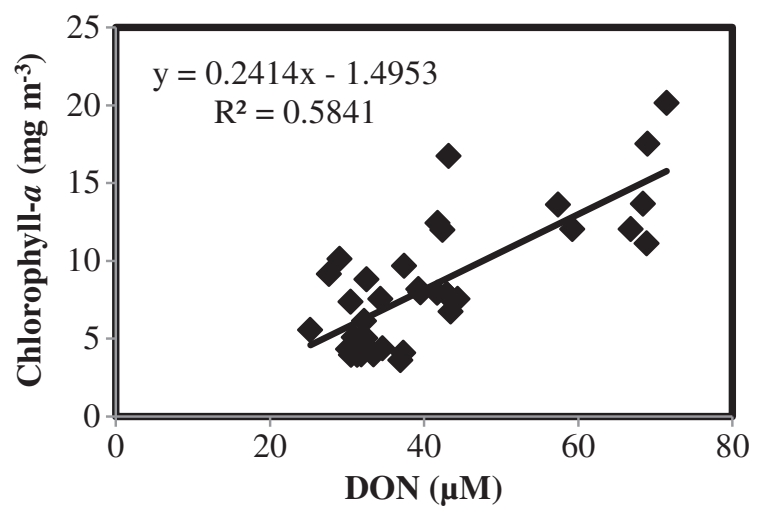

Figure 4. Scatter plot between DON (independent variable) and Chl-a (dependent variable) during May 2011 at Chilika lagoon.

Table 2. Range of concentrations ( $\mu M-N$ ) of urea from some coastal and estuarine sites.

\begin{tabular}{lcl}
\hline Location & $\begin{array}{c}\text { Range of } \\
\text { concentration }\end{array}$ & \multicolumn{1}{c}{ Reference } \\
\hline Great South Bay, New York & $0.6-9.4$ & Kaufman et al. $(1983)$ \\
Mankyung and Dongjin River Estuary, Korea & $0.6-4.3$ & Cho et al. $(1996)$ \\
Chesapeake Bay, Mainstem & $<0.01-8.16$ & Lomas et al. $(2002)$ \\
Florida Bay, Florida & $0.36-1.7$ & Glibert et al. $(2004)$ \\
Chicamicomico R, Chesapeake Bay, & $<0.01-24.2$ & Glibert et al. $(2005)$ \\
Maryland; Kings Creek, Chesapeake & & \\
Bay, Maryland and Coastal Bays, Maryland & & \\
Southwest coast of India & $0.05-1.34$ & Gopinath et al. $(2002)$ \\
Chilika Lagoon, India & $0.02-4.16$ & Present study \\
\hline
\end{tabular}




\subsection{Chlorophyll (Chl-a), dissolved oxygen (DO) and primary productivity $(P P)$}

Low water column chlorophyll in the southern sector during most part of this study (figure 3) could be attributed to less availability of inorganic nutrients, favouring the growth of slow growing seagrass compared to the first growing phytoplankton (Duarte 1995) in this region. Previously, Nayak et al. (2004) reported highest Chl- $a$ concentration as high as $54.04 \mathrm{mg} \mathrm{m}^{-3}$ from the northern sector in May 2001, immediately after the new mouth opening at Satapada. No such high concentrations were recorded in the present observation, but it was well within the range $\left(0.37-23.40 \mathrm{mg} \mathrm{m}^{-3}\right)$ reported by Panigrahi et al. (2007). The observed values of dissolved nutrients as well as chlorophyll in the lagoon during 2001-2002 were higher (Mishra and Shaw 2003; Panigrahi et al. 2007) than those observed in the present study. This could be attributed to the difference in annual rainfall between the two years. Excess rainfall in 2001-2002 resulted higher runoff from the surrounding catchment area, which contained a higher nutrient load compared to 2011, when the annual rainfall in adjacent Puri and Ganjam district (consisting the major catchment area) was 44.8 and $42.2 \%$ less than the normal annual rainfall (Annual report on natural calamities, 2011-2012). The significance of Chl- $a$ distribution in the lagoon was tested by stepwise multiple regression analysis. The dependent variable was Chl- $a$ concentration and the independent variables were salinity $(\mathrm{S})$, water temperature (WT), $\mathrm{NH}_{4}^{+}-\mathrm{N}$, urea, $\mathrm{NO}_{3}^{-}-\mathrm{N}$ and $\mathrm{PO}_{4}^{3-}-\mathrm{P}$. Statistical analysis revealed a significant correlation between Chl- $a$ and independent variables tested with $76.5 \%$ (table 3 ) explained variability (equation 1). The explained variability of Chl- $a$ distribution found $5.3 \%$ for salinity, $10 \%$ for temperature, $29.4 \%$ for $\mathrm{NH}_{4}^{+}-\mathrm{N}$, $13.6 \%$ for urea, 9.8 for $\mathrm{NO}_{3}^{-}-\mathrm{N}, 2.6$ for $\mathrm{NO}_{2}^{-}-\mathrm{N}$ and $5.8 \%$ for $\mathrm{PO}_{4}^{3-}-\mathrm{P}$. The results clearly indicated that $\mathrm{NH}_{4}^{+}-\mathrm{N}$ and urea in the lagoon water play a predominant role $(43 \%)$ on the variation of Chl- $a$ concentration over other biochemical parameters. These results were in association with the in situ observation made by Fertig et al. (2013) depicting the greatest uptake preference of ammonium, followed by urea, and nitrate by phytoplankton in Chincoteague Bay, Maryland, USA.

$$
\begin{aligned}
\text { Chl }-a= & 41.1-0.029 \mathrm{~S}-1.11 \mathrm{WT}+0.66 \mathrm{NH}_{4}^{+}-\mathrm{N} \\
& +4.27 \text { Urea }+0.241 \mathrm{NO}_{3}^{-}-\mathrm{N} \\
& +8.7 \mathrm{NO}_{2}^{-}-\mathrm{N}+3.70 \mathrm{PO}_{4}^{3-}-\mathrm{P}
\end{aligned}
$$

Day-time DO concentration in the lagoon remained high with a high degree of saturation.
Table 3. Multiple regression analysis with a stepwise variable selection.

\begin{tabular}{lcccc}
\hline Predictor & $r^{2}$ & & & \\
(stepwise) & $p$ & $f$ & $n$ \\
\hline $\mathrm{S}$ & 5.3 & 0.432 & 0.22 & 24 \\
$\mathrm{WT}$ & 15.3 & 0.287 & 1.36 & 24 \\
$\mathrm{NH}_{4}^{+}$ & 44.7 & 0.035 & 3.79 & 24 \\
$\mathrm{Urea}$ & 58.3 & 0.033 & 4.07 & 24 \\
$\mathrm{NO}_{3}^{-}$ & 68.1 & 0.046 & 3.86 & 24 \\
$\mathrm{NO}_{2}^{-}$ & 70.7 & 0.08 & 2.48 & 24 \\
$\mathrm{PO}_{4}^{3-}$ & 76.5 & 0.041 & 4.33 & 24 \\
\hline
\end{tabular}

Dependent variables: Chl- $a$, independent variables: salinity (S), water temperature (WT), $\mathrm{NH}_{4}$, urea, $\mathrm{NO}_{3}^{-}, \mathrm{NO}_{2}^{-}$, $\mathrm{PO}_{4}^{3-} \cdot r^{2}=$ coefficient of multiple determination (i.e., the percentage of the response variable variation that is explained by the linear model), $p=$ probability level, $f=$ critical value of the F-distribution, $n=$ number of observations.

The DO concentrations are often regulated by benthic seagrass species in the southern sector where the water column chlorophyll concentration is relatively low (figure 2). Low DO values in the southern sector during August, could be explained by the stresses caused by the freshwater intrusion, on the halophilic seagrass species (Collier et al. 2014). Positive apparent oxygen utilization (AOU) values (less than saturation DO) were found at lower Chl- $a$ abundance (in August) and low to moderately negative AOU values (DO supersaturation) at relatively higher Chl- $a$ (in pre- and postmonsoon months). Although, Chl- $a$ concentration reached the maximum during December followed by May and August, AOU values were more negative in May compared to December. Muduli et al. (2012) recently reported a gradual decrease of bacterial respiration from monsoon (August) to premonsoon (May) accompanied with an increase in air-water $\mathrm{CO}_{2}$ efflux (increase in biological utilization of oxygen) for two successive years (2009 and 2010 ) in the same lagoon. Heavy precipitation in the monsoon months, characterized by low salinity and high turbidity led to a significant decrease in $\mathrm{PP}$ in the lagoon (ANOVA, $p<0.01$ ) compared to non-monsoon months. Among the sectors, central sector showed highest NPP followed by northern, southern and outer channels both in August and December (figure 5). In all the three seasons, i.e., pre-monsoon $\left(r^{2}=0.54, p=0.01\right)$, monsoon $\left(r^{2}=0.49, p=0.016\right)$ and post-monsoon $\left(r^{2}=0.66, p<0.003\right)$, Chl- $a$ showed significant positive correlation with NPP (11 stations data) at varying degree of significance. This observation supported the use of Chl- $a$ as one of the best proxy of phytoplankton biomass for studies of primary productivity (Huot et al. 2007). 


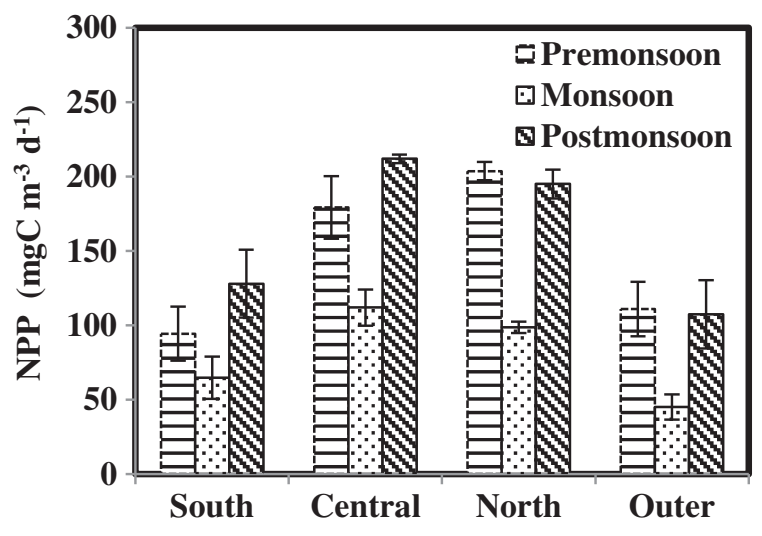

Figure 5. Spatio-temporal variation of NPP in the Chilika lagoon, 2011.

\subsection{Trophic status index (TSI) of the lagoon}

Trophic state index deviations (Carlson 1977, 1991; Kratzer and Brezonik 1981) are known to be important for assessing historical trends in nutrient limitation in cases where spatio-temporal monitoring data on total nutrient concentrations are available. In the derivations of original TSI, Carlson (1977) intended to build equations that would produce the same TSI value for a particular lagoon, irrespective of whether Chl- $a$, phosphorus, or transparency was used to calculate the index of trophic state. The accuracy of the index values based on Chl- $a$, phosphorus, and transparency depends on the assumption that phosphorus was the main algal biomass-limiting factor, and that underwater light climate was dominated by phytoplankton rather than non-algal turbidity. In reality, these assumptions are not easy to be demonstrated in many water bodies, and there are often obvious differences in the calculated trophic state (Matthews et al. 2002; An and Park 2003; Lee et al. 2010). In this case, Carlson (1991) suggested giving priority to biological parameters such as Chl- $a$ that represents visible symptoms of eutrophication, when classifying a lagoon's trophic status. Several workers supported Carlson's idea that the trophic state index determined with Chl- $a$ would provide a better indication of lagoon trophic state than the one determined with total phosphorus concentrations or transparency (e.g., Matthews et al. 2002; An and Park 2003; Lee et al. 2010).

In the present study, TSI $\mathrm{SD}$ in all the four sectors ranged between 57.01 and 78.48 with the highest values observed in the northern sector irrespective of the seasons. TSI values calculated from SD, TN, $\mathrm{TP}$ and Chl- $a$ at different sectors in three different seasons were given in figure 6 . The mean annual $\mathrm{TSI}_{\mathrm{SD}}$ for the whole lagoon was calculated to be 63.7 which indicated the clear eutrophic nature in terms of Secchi disk transparency. $\mathrm{TSI}_{\mathrm{CHL}}$ showed
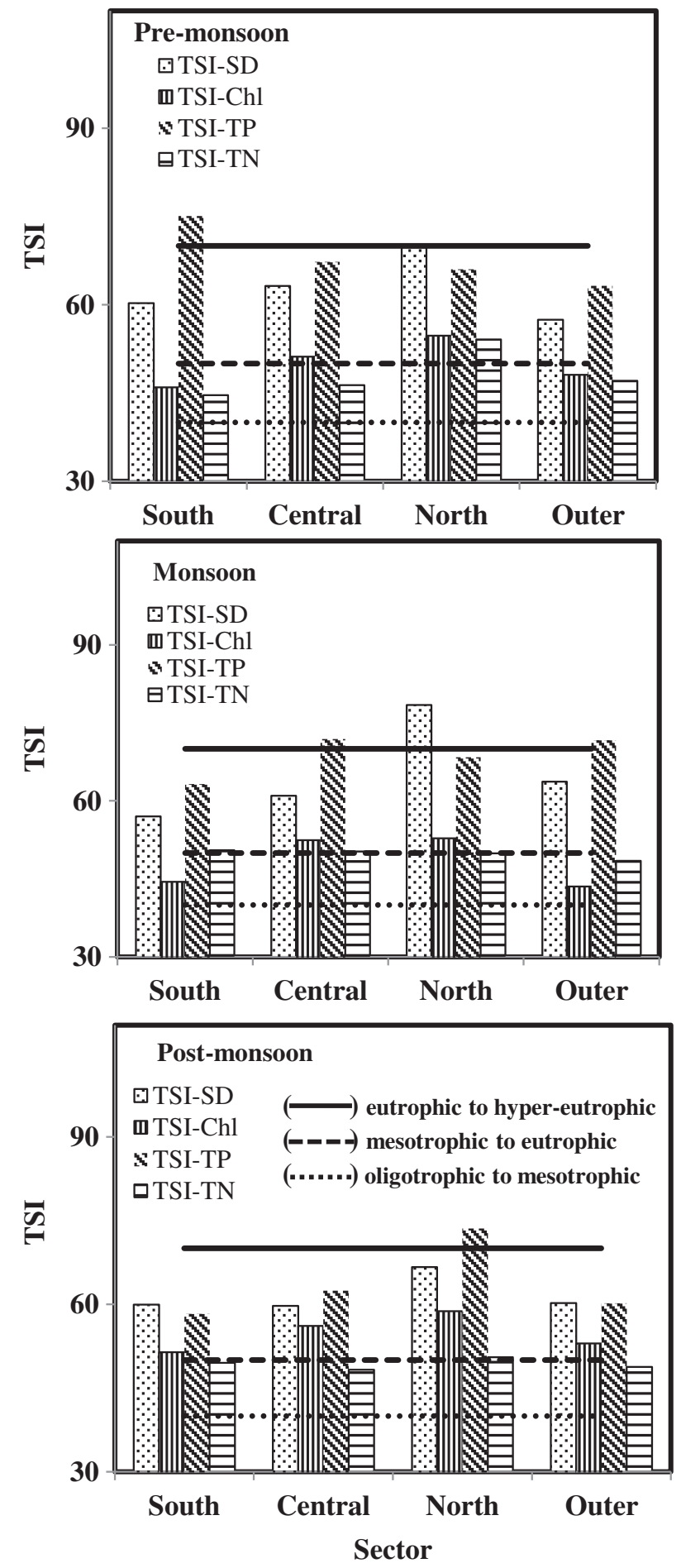

Figure 6. Seasonal variation in trophic state indices calculated from Secchi disk transparency (TSI-SD), Chl$a$ (TSI-Chl), total phosphorus and total nitrogen (TSITN). Dotted line represents transition from oligotrophic to mesotrophic $(\ldots$.$) , dashed line \left(-\right.$ - $^{-}$represents transition from mesotrophic to eutrophic condition and solid line $(-)$ represents transition from eutrophic to hypereutrophic condition.

substantially lower values than $\mathrm{TSI}_{\mathrm{SD}}$ all over the lagoon throughout the study period. These lower values of $\mathrm{TSI}_{\mathrm{CHL}}$ than $\mathrm{TSI} \mathrm{SD}_{\mathrm{SD}}$, clearly indicated that 
something other than algae, perhaps colour, sediment particle or non-algal seston, was contributing to the light attenuation. Similarly, near the outer channel, the TSI $\mathrm{SD}_{\mathrm{SD}}$ was mostly recorded very close to 60 , although the chlorophyll was relatively less. Being the mouth region, the suspended particle could be less dominated by the algal particle compared to the inorganic suspension caused by regular tidal activities. TSI $_{\mathrm{CHL}}$ showed greater spatiotemporal variability than that of $\mathrm{TSI}_{\mathrm{SD}}$. $\mathrm{TSI}_{\mathrm{CHL}}$ also revealed that mesotrophic nature prevailed at the southern sector and outer channel during both May and August, whereas northern and central sector remained marginally eutrophic during these periods. In contrast, during December, the lagoon was in relatively enriched trophic state irrespective of the sectors with highest intensity at the northern part.

When $\mathrm{TSI}_{\mathrm{CHL}}$ is equal to or greater than $\mathrm{TSI}_{\mathrm{TP}}$, phosphorus generally is limiting to algal growth. When $\mathrm{TSI}_{\mathrm{CHL}}$ is substantially lower than $\mathrm{TSIT}_{\mathrm{TP}}$, this indicates that there is less algal material present than expected, based on total phosphorus, and that some other factors may be limiting. In the same manner, the deviation between $\mathrm{TSI}_{\mathrm{CHL}}$ and $\mathrm{TSI}_{\mathrm{TN}}$ can be used to infer whether or not nitrogen limitation occurs. Those relationships have been extensively used by most related studies (e.g., Matthews et al. 2002; An and Park 2003; Lee et al. 2010). For instance, Matthews et al. (2002) employed the concept of TSI differences to assess the trophic state and nutrient limitation of Lake Whatcom (WA, USA). All the values for $\mathrm{TSI}_{\mathrm{TP}}$ remained between eutrophic to hyper-eutrophic classes with mean annual value of 67 in the lagoon. Significant higher $\mathrm{TSI}_{\mathrm{TP}}$ than $\mathrm{TSI}_{\mathrm{CHL}}$ indicated that there was less algal material present than expected based on total phosphorus, and that some additional factors other than phosphorous may be limiting for the algal growth in the lagoon. Mean lagoon $\mathrm{TSI}_{\mathrm{TN}}$ during May, August and December, 2011 was found to be 49-50, respectively. The monsoonal input of riverine nutrients shifted the tragic condition from mesotrophic to eutrophic nature of the lagoon in terms of TSI $\mathrm{TN}_{\mathrm{TN}}$ values. The trophic state index determined with Chl- $a$ presented lower value (in all the sectors) than those determined with total nitrogen, total phosphorus, and transparency during monsoon, indicating that non-algal turbidity rather than nitrogen and phosphorus limited phytoplankton growth in the lagoon. On the contrary, during pre-monsoon (May) and post-monsoon (December), the trophic state index determined with Chl- $a$ was found lower than $\mathrm{TSI}_{\mathrm{TP}}$ and $\mathrm{TSI}_{\mathrm{SD}}$, but relatively higher than $\mathrm{TSI}_{\mathrm{TN}}$. This result indicates a probable $\mathrm{N}$ deficiency in addition to non-algal turbidity causing limited algal growth in the lagoon water during the non-monsoonal months.

\section{Conclusion}

The present study revealed that primary productivity at Chilika lagoon was largely influenced by dissolved $\mathrm{NH}_{4}^{+}-\mathrm{N}$ and urea-N concentration and the lagoon remained eutrophic during December, with concentrations of Chl- $a$ regularly exceeding $10 \mu \mathrm{g} \mathrm{L}^{-1}$ over the period. During the dry season, DON could explain $58 \%$ variability of Chl- $a$ concentration in the lagoon, which showed the relative importance of regenerated DON over anthropogenic DON to the primary producer when DIN:DIP was $<16$. Our present understanding of the linkages between nitrate, ammonium and urea fertilization and their transport to downstream aquatic systems is limited (Silva et al. 2005; Di and Cameron 2008). The influence of in situ biogeochemical processes like DNRA, denitrification, mineralization, etc. and extent of sediment-water coupling could be of equal importance compared to the transport processes in regulating the nutrient status of the shallow lagoon and corresponding productivity. Further research to quantify the relative importance of these various processes will be useful to protect coastal waters like Chilika from rapid eutrophication incidences. This present study revealed dynamic inter-sectoral and inter-seasonal changes in the trophic status of the Chilika lagoon, influenced by huge river runoff associated with the southwest monsoon. From the present study, it can be concluded that the trophic state of the lagoon was primarily controlled by the combined effect of turbidity and nitrogen availability during May and December, while the state was directly influenced by non-algal light attenuation during intense monsoon (August). Slightest perturbation in the lagoon water quality, due to the alteration in precipitation, wind, pollution source, etc., can modify these trophic states of different sectors between any two consecutive months, seasons or years. The TSI can be a valuable tool for monitoring lagoon eutrophication and also as a simple but effective scientific technique for investigations where an objective standard of trophic state is necessary, but a more complete picture of the lagoon trophic state can be achieved only by applying several indicators (including physical, chemical, and biological) simultaneously.

\section{Acknowledgements}

The authors are grateful to the Secretary, MoES, Government of India, and Project-Director, ICMAM for the encouragement and support. Authors are also grateful to the Indian Navy (INS Chilika) for logistic support rendered during the course of this investigation. They are also thankful 
to the research staff of Andhra University for their support in executing the fieldwork. This study is a part of MoES-ICMAM's comprehensive project "Ecosystem Modelling for Chilika Lagoon".

\section{References}

Allen A E, Howard-Jones M H, Booth M G, Frischer M E, Verity P G, Bronk D A and Sanderson M P 2002 Importance of heterotrophic bacterial assimilation of ammonium and nitrate in the Barents Sea during summer; J. Mar. Syst. 38 93-108.

An K G and Park S S 2003 Influence of seasonal monsoon on the trophic state deviation in an Asian reservoir; Water Air Soil Pollut. 145 267-287.

Annual report on natural calamities 2011-2012 Revenue \& Disaster Management Department, Special Relief Commissioner, Government of Odisha, pp. 7-8.

Berman T and Bronk D A 2003 Dissolved organic nitrogen: A dynamic participant in aquatic ecosystems; Aq. Microb. Ecol. 31 279-305.

Bronk D and Glibert P 1993 Application of a 15N tracer method to the study of dissolved organic nitrogen uptake during spring and summer in Chesapeake Bay; Mar. Biol. 115 501-508.

Carlson R E 1977 A trophic state index for lakes; Limnol. Oceanogr. 22 361-369.

Carlson R E 1991 Expanding the trophic state concept to identify non-nutrient limited lakes and reservoirs; In: Enhancing the states's lake management programs, pp. 59-71.

Cho B C, Park M G, Shim J H and Azam F 1996 Significance of bacteria in urea dynamics in coastal surface waters; Mar. Ecol. Prog. Ser. 142 19-26.

Cochlan W P and Wikner J 1993 Nitrogen uptake by sizefractionated micro-organisms in the Gulf of Bothnia, Sweden; The Oceanography Society Meeting, Seattle, WA (abstract only).

Collier C J, Villacorta-Rath C, van Dijk K-J, Takahashi M and Waycott M 2014 Seagrass proliferation precedes mortality during hypo-salinity events: A stress-induced morphometric response; PLoS One 9(4) e94014, doi: 10.1371/journal.pone.0094014.

Cozzi S, Mistaro A, Sparnocchia S, Colugnati L, Bajt O and Toniatti L 2014 Anthropogenic loads and biogeochemical role of urea in the Gulf of Trieste; Sci. Total Environ. 493 $271-281$.

Di H J and Cameron K C 2008 Sources of nitrous oxide from N-15-labelled animal urine and urea fertilizer with and without a nitrification inhibitor, dicyandiamide (DCD); Aust. J. Soil Res. 46 76-82, doi: 10.1071/SR07093.

Duarte C M 1995 Submerged aquatic vegetation in relation to different nutrient regimes; Ophelia 41(1) 87-112.

Dunn Ryan J K, Welsh David T B, Jordan Mark A, Waltham Nathan J, Lemckert Charles J and Teasdale Peter R 2012 Benthic metabolism and nitrogen dynamics in a sub-tropical coastal lagoon: Microphytobenthos stimulate nitrification and nitrate reduction through photosynthetic oxygen evolution; Estuarine Coast. Shelf Sci. $113272-282$.

Fertig B, O'Neil J M, Beckert K A, Cain C J, Needham D M, Carruthers T J B and Dennison W C 2013 Elucidating terrestrial nutrient sources to a coastal lagoon, Chincoteague Bay, Maryland, USA; Estuarine Coast. Shelf Sci. 116 1-10.

Ganguly D, Robin R S, Vishnu V K, Muduli P R, Abhilash K R, Patra S and Subhramanian B R 2013 Variable response of two tropical phytoplankton species at different salinity and nutrient condition; J. Exp. Mar. Biol. Ecol. 440 244-249.

Glibert P M, Garside C, Fuhrman J and Roman M R 1991 Time- and size-dependent coupling of organic and inorganic nitrogen uptake and $\mathrm{NH}_{4}^{+}$regeneration in the plume of the Chesapeake Bay, and its regulation by large heterotrophs; Limnol. Oceanogr. 36 895-909.

Glibert P M, Magnien R, Lomas M W et al. 2001 Harmful algal blooms in the Chesapeake and coastal bays of Maryland, USA: Comparison of 1997, 1998, and 1999 events; Estuaries 24 875-883.

Glibert P M, Heil C A, Hollander D, Revilla M, Hoare A, Alexander J and Murasko S 2004 Evidence for dissolved organic nitrogen and phosphorus uptake during a cyanobacterial bloom in Florida Bay; Mar. Ecol. Prog. Ser. 280 73-83.

Glibert P M, Trice T M, Michael B and Lane L 2005 Urea in the tributaries of the Chesapeake and coastal bays of Maryland; Water Air Soil Pollut. 160 229-43.

Glibert P M, Harrison J, Heil C and Seitzinger S 2006 Escalating worldwide use of urea - a global change contributing to coastal eutrophication; Biogeochemistry $\mathbf{7 7}$ 441-463.

Grasshoff K, Kremlimg K and Ehrhardt M 1999 Analysis by electrochemical methods; In: Methods of sea water analysis, Wiley VCH, pp. 159-226.

Gopinath A, Joseph N, Sujatha C H and Nair S M 2002 Forms of nitrogen $\left(\mathrm{NO}_{3}^{-}-\mathrm{N} ; \mathrm{NO}_{2}^{-}-\mathrm{N}\right.$ and $\mathrm{NH}_{2} \mathrm{CONH}_{2}-\mathrm{N}$ ) and their relations to A.O.U. in the Indian coastal waters of Arabian sea; Chemistry and Ecology 18 233-244.

Gupta G V M, Sarma V V S S, Robin R S, Raman A V, Jai Kumar M, Rakesh M and Subramanian B R 2008 Influence of net ecosystem metabolism in transferring riverine organic carbon to atmospheric $\mathrm{CO}_{2}$ in a tropical coastal lagoon (Chilika lagoon, India); Biogeochem. 87 265285.

Huot Y M, Babin F, Bruyant C, Grob M S and Twardowski H C 2007 Does chlorophyll- $a$ provide the best index of phytoplankton biomass for primary productivity studies? Biogeosci. Discuss. 4 707-745.

Kaufman Z G, Lively J S and Carpenter E J 1983 Uptake of nitrogenous nutrients by phytoplankton in a barrier island estuary: Great South Bay, New York; Estuarine Coast. Shelf Sci. 17 483-493.

Kanuri Vishnu Vardhan, Muduli Pradipta R, Robin R S, Charan Kumar B, Lovaraju A, Ganguly D, Sivaji Patraa, Nageswara Rao G, Raman A V and Subramanian B R 2013 Plankton metabolic processes and its significance on dissolved organic carbon pool in a tropical brackish water lagoon; Cont. Shelf Res. 61-62 52-61.

Kratzer C R and Brezonik P L 1981 A carlson-type trophic state index for nitrogen in florida lakes; Water Resour. Bull. 17 713-715.

Kudela R M and Cochlan W P 2000 Nitrogen and carbon uptake kinetics and the influence of irradiance for a red tide bloom off southern California; Aquat. Microb. Ecol. 21 31-47.

Labry C, Herbland A and Delmas D 2002 The role of phosphorous on planktonic production of the Gironde Plume waters in the Bay of Biscay; J. Plankton Res. 24(2) 97-117.

Lee J, Kim J M, Kim D S, Hwang S J and An K G 2010 Nutrients and chlorophyll- $a$ dynamics in a temperate reservoir influenced by Asian monsoon along with in situ nutrient enrichment bioassays; Limnology 11 49-62.

Lomas M W, Trice T M, Glibert P M, Bronk D A and McCarthy J J 2002 Temporal and spatial dynamics of urea uptake and regeneration rates, and concentrations in Chesapeake Bay; Estuaries 25 469-482. 
Mace K A, Artaxo P and Duce R A 2003 Water-soluble organic nitrogen in Amazon Basin aerosols during the dry (biomass burning) and wet seasons; J. Geophys. Res.: Atmos. 108 4512, doi: 10 1029/2003JD003557.

Mahapatro D, Panigrahy R C and Panda B 2013 Coastal Lagoon: Present status and future challenges; Int. J. Mar. Sci. 3(23) 178-186.

Matthews R, Hilles M and Pelletier G 2002 Determining trophic state in Lake Whatcom, Washington (USA), a soft water lake exhibiting seasonal nitrogen limitation; Hydrobiologia 468 107-121.

Middelburg J J and Nieuwenhuize J 2000 Nitrogen uptake by heterotrophic bacteria and phytoplankton in the nitrate-rich Thames estuary; Mar. Ecol. Prog. Ser. 203 13-21.

Mishra P K and Shaw B P 2003 Spatiotemporal variation of optically active substances; In: The coastal water off Orissa from Rishikulla to Dharma; Indian J. Mar. Sci. 32 133-140.

Miyazaki Y, Kawamura K and Sawano M 2010 Size distributions of organic nitrogen and carbon in remote marine aerosols: Evidence of marine biological origin based on their isotopic ratios; Geophys. Res. Lett. 37 L06803, doi: 10 1029/2010GL042483.

Muduli P R, Kanuri Vishnu Vardhan, Robin R S, Charan Kumar B, Sivaji Patra, Raman A V, Nageswarara Rao G and Subramanian B R 2012 Spatio-temporal variation of $\mathrm{CO}_{2}$ emission from Chilika Lake, a tropical coastal lagoon, on the east coast of India; Estuarine Coast. Shelf Sci. 113 305-313.

Muduli P R, Kanuri V V, Robin R S, Charan Kumar B, Patra S, Raman A V, Nageswara Rao G and Subramanian B R 2013 Distribution of dissolved inorganic carbon and net ecosystem production in a tropical brackish water lagoon, India; Cont. Shelf Res. 64 75-87.

Nayak B K, Acharya B C, Panda U C, Nayak B B and Acharya S K 2004 Variation in the water quality in the Chilika lake; Indian J. Mar. Sci. 33 164-169.

Panigrahi S, Acharya B C, Panigrahy R C, Nayak B K, Banarjee K and Sarkar S K 2007 Anthropogenic impact on water quality of Chilika lagoon RAMSAR site:
A statistical approach; Wetlands Ecol. Manag. 15 113-126.

Panigrahi S, Wikner J, Panigrahy R C, Satapathy K K and Acharya B C 2009 Variability of nutrients and phytoplankton biomass in a shallow brackish water ecosystem (Chilika lagoon, India); Limnology 10 73-85.

Pujo-Pay M and Raimbault P 1994 Improvement of the wet-oxidation procedure for simultaneous determination of particulate organic nitrogen and phosphorous collected on filters; Mar. Ecol. Prog. Ser. 105 203-207.

Revilla Marta, Jeffrey Alexander and Glibert Patricia M 2005 Urea analysis in coastal waters: Comparison of enzymatic and direct methods; Limnol. Oceanogr. Methods $\mathbf{3}$ 290-299.

Rysgaard S, Thamdrup B and Risgaard-Petersen $\mathrm{N}$ et al. 1998 Seasonal carbon and nutrient mineralization in a high-Arctic coastal marine sediment, Young Sound, Northeast Greenland; Mar. Ecol. Prog. Ser. 175 261-276.

Seitzinger S P, Kroeze C, Bouwman A F, Caraco N, Dentener F and Styles R V 2002 Global patterns of dissolved inorganic and particulate nitrogen inputs to coastal systems: Recent conditions and future projections; Estuaries 25 640-655.

Siddiqui S Z and Rao K V 1995 Limnology of Chilika lake; In: Fauna of Chilika Lake (Wetland Ecosystem Series I), by Director of Zoological Survey of India Calcutta: Zoological Survey of India.

Silva R G, Cameron K C, Di H J and Jorgensen E E 2005 A lysimeter study to investigate the effect of dairy effluent and urea on cattle urine N losses, plant uptake and soil retention; Water Air Soil Pollut. 164 57-78.

UNESCO 1994 Protocols for the Joint Global Ocean Flux Study; Manuals and Guides 29, 190p.

Valderrama J C 1981 The simultaneous analysis of total nitrogen and total phosphrous in natural waters; Mar. Chem. 10 109-122.

Violaki K, Zarbas P and Mihalopoulos N 2010 Long-term measurements of dissolved organic nitrogen (DON) in atmospheric deposition in the Eastern Mediterranean: Fluxes, origin and biogeochemical implications; Mar. Chem. 120 179-186. 